\title{
$\mathrm{LPB}$ 용 $\mathrm{MCMB}$ 부극 도전재로 $\mathrm{VGCF}$ 를 첨가한 부극의 특성 연구
}

\author{
진봉수 ${ }^{\dagger}$ 도칠훈 · 문성인 · 윤문수 · 정재국* - 남효덕** - 박희구*** \\ 한국전기연구원, *새한에너테크 \\ $* *$ 영남대학교, ***계명대학교 \\ (2004년 6월 24일 접수 : 2004년 8월 11일 채택)
}

\section{Characteristics of MCMB Anode with VGCF As a Conducting Agent for LPB}

\author{
Bong-Soo Jin ${ }^{\dagger}$, Chil-Hoon Doh, Seong-In Moon, Mun-Soo Yun, Jae-Kook Jeong*, Hyo-Duk Nam**, and Hei-Gu Park*** \\ Korea Electrotechnology Research Institute, Changwon, Gyeongnam, 641-120, Korea \\ *Saehan Enertech, Chungiu, Chungbuk, Korea \\ **Yeungnam University, Gyeongsan, Gyeongbuk, 712-749, Korea \\ ***Keimyung University, Daegu, 704-701, Korea \\ (Received June 24, 2004 : Accepted August 11, 2004)
}

\begin{abstract}
초 록
Vapor grown carbon fiber(VGCF)가 각기 달리 첨가된 부극으로 제조된 $\mathrm{LPB}$ 의 특성을 조사하였다. MCMB를 활물 질로, $\mathrm{VGCF}$ 를 도전재로 사용하였을 경우, 전지의 내부저항과 1 차 $\mathrm{Ah}$ 효율은 $\mathrm{VGCF}$ 첨가량이 많아질수록 감소하였고 방전 용량과 이용률은 증가하였다. $6 \mathrm{wt} \%$ 의 VGCF가 첨가된 부극으로 제조된 전지가 최저 임피던스를 나타내었고, $8 \mathrm{wt} \%$ 의 $\mathrm{VGCF}$ 첨가한 경우는 $\mathrm{VGCF}$ 를 첨가하지 않은 것과 유사한 임피던스를 나타내었다. $6 \mathrm{wt} \%$ 의 $\mathrm{VGCF}$ 가 첨가 된 부극으로 제조된 전지가 최고의 전지 특성을 나타내었다. 이 전지의 내부저항은 실온에서 $0.918 \Omega$ 이였고, $2 \mathrm{C}$ 에서의 고율 방전 시의 용량은 $93 \%$ 였다. 율 특성과 수명 특성은 $4 \mathrm{wt} \%$ 와 $6 \mathrm{wt} \%$ 의 VGCF가 첨가된 부극으로 제조된 전지 가 타 전지에 비해 우수하였고 두 경우는 매우 유사한 결과를 나타내었다. $6 \mathrm{wt} \%$ 의 VGCF가 첨가된 부극으로 제조된 전지의 경우, 방전 용량은 충방전 사이클링을 진행함에 따라 서서히 감소하여 100 회에서 $178 \mathrm{mAh} / \mathrm{g}$ 의 비용량을 나타 내었으며 이후에는 완만한 감소경향을 나타내었다. $6 \mathrm{wt} \%$ 의 VGCF 첨가의 경우 이용률은 100 회에서 $90 \%$ 이상으로 $4 \mathrm{wt} \%$ 의 $\mathrm{VGCF}$ 가 첨가된 부극으로 제조된 전지 보다 우수하였다.
\end{abstract}

\begin{abstract}
An investigation upon the characterization of MCMB anodes with different vapor grown carbon fiber (VGCF) content for application in lithium polymer battery(LPB) was carried out. When VGCF material was used as conducting agent with MCMB active material, the impedance and the initial coulombic efficiency of test cells were found to decrease with the increasing amount of VGCF. On the other hand, as a function of added VGCF the discharge capacity and the utilization linearly with increased. Impedance of test cell with MCMB anode containing $6 \mathrm{wt} \%$ VGCF exhibited the lowest value whereas the impedance of $8 \mathrm{wt} \%$ VGCF contained anode was similar to that of MCMB anode without VGCF. Interestingly, $6 \mathrm{wt} \%$ VGCF contained anode showed the best battery characteristics. Internal resistance and rate capacity of the cell were, respectively, $0.918 \Omega$ at $25 \mathrm{C}$ and $93 \%$ at $2 \mathrm{C}$. Generally, rate capability and the cycleability of MCMB based test cells with $4 \sim 6 \mathrm{wt} \%$ VGCF content exhibited better results than the other cells. In the case of $6 \mathrm{wt} \%$ VGCF containing anode, the discharge capacity of the cell faded slowly with an ultimate charge-discharge cycling capacity of $178 \mathrm{mAh} / \mathrm{g}$ at the 100 th cycle. Thereafter, the discharge capacity faded negligibly and the utilization of the cell at the 100th cycle was more than $90 \%$. The effect of addition of VGCF is discussed in detail.
\end{abstract}

Key words: LPB, Impedance, Rate capability, Ist Ah efficiency, VGCF.

\section{1. 서 론}

최근 전자기기들의 급속한 발달과 함깨 에너지 밀도가 높은
고성능 2 차 전지의 개발이 요구되고 있으며, 이를 위한 많은 연 구가 진행되고 있다. ${ }^{1-3)}$ 좋은 성능의 2 차 전지는 낮은 내부저항 을 가지고 있으며, 내부저항은 율 특성 그리고 수명 특성에 밀 접한 관계를 가지고 있다.4) 또한 내부저항은 전극의 구성 물질 과 혼합비 그리고 전극 충의 압착도 등에 의해 많은 영향을 받

${ }^{\dagger} \mathrm{E}-\mathrm{mail}$ : bsjin@keri.re.kr 
고 있는 것으로 알려져 있다.5)

본 연구에서는 부극 활물질인 mesophase carbon microbead 2528(MCMB)와 결합제인 polyvinylidenefluoride(PVDF), 그리 고 도전재인 super P black(SPB)으로 구성된 부극을 사용하여 $\mathrm{LPB}$ 를 제조하였다. 전극 활물질 사이의 전자 전도를 높이기 위 해 구형보다는 섬유형의 도전제가 효과적일 것으로 예상되어 부 극 도전재를 구형인 $\mathrm{SPB}$ 에서 섬유 형태의 VGCF로 대체하여 전지 특성을 실험하였다. $\mathrm{VGCF}$ 의 첨가량을 $0,2,4,6,8 \mathrm{wt} \%$ 로 달리한 부극으로 제조된 $\mathrm{LPB}$ 의 내부저항과 전지 특성을 연구 하였다.

\section{2. 실 험}

용매인 N-methyl-2-pyrrolidinone(NMP)에 결합제인 PVDF를 첨가하여 2 시간동안 교반하여 $\mathrm{PVDF}$ 를 완전히 용해한 후, 활 물질인 $\mathrm{MCMB}$ 와 도전재인 $\mathrm{VGCF}$ 를 첨가하였다. $\mathrm{SPB} / \mathrm{MCMB} /$ $\mathrm{VGCF}$ 의 중량비를 9/91/0, 9/89/2, 9/87/4, 9/95/6, 9/83/8로 하 여 지르코니아 볼과 함께 3시간 동안 $200 \mathrm{rpm}$ 으로 attrition milling 을 행하여 부극 합제를 제조하였다. 합제를 구리 집전체 에 도포하여 $110^{\circ} \mathrm{C}$ 건조기에서 2 시간 건조시켰으며, 전극 규격 $3.2 \times 5.2 \mathrm{~cm}^{2}$ 로 부극을 제조하였다. 정극은 부극과 동일한 방법 으로 $\mathrm{LiCoO}_{2}$ 와 $\mathrm{SPB}, \mathrm{PVDF}$ 를 $92 / 4 / 4 \mathrm{wt} \%$ 의 조성으로 합제 를 만든 후 알루미늅 집전체에 도포하였으며, 전극 규격 $3.0 \times$ $5.0 \mathrm{~cm}^{2}$ 의 크기로 제조하였다. 각각의 정극과 부극을 twin roller로 초기 두께 대비 압착율을 $70 \%$ 로 하여 압착하고 $130^{\circ} \mathrm{C}$ 에서 24 시간 진공건조한 후 실험에 사용하였다. 격리막은 acrylonitrile methyl methacrylate styrene terpolymer(AMS)가 polypropylene 다공성 막에 약 $10 \mathrm{um}$ 두께로 도포한 막을 사용 하였다. 정극, 격리막, 부극으로 적층된 것에 $1.0 \mathrm{M} \mathrm{LiPF}_{6}+$ $\mathrm{EC}: \mathrm{EMC}: \mathrm{DMC}: \mathrm{PC}(4: 3: 3: 1 \mathrm{vol} \%)$ 전해액을 $0.5 \mathrm{~mL}$ 첨가하 여 전지를 제조하였다. 제조한 전지는 24 시간 상온에서 방치하
여 aging 을 행한 후에 특성 측정에 사용하였다. 동일한 정극과 각기 다른 $\mathrm{VGCF}$ 첨가 조성의 부극으로 구성된 시험 전지들을 화성한 후, 방전 상태의 전지를 사용하여 $1 \mathrm{mHz} 1 \mathrm{MHz}$ 의 주 파수 범위에서 2단자법으로 $\mathrm{AC}$ impedance를 측정하여 내부저 항을 측정하였다. Table 1에 나타낸 바와 같이 초기 충-방전, 출력, 수명 특성을 측정하여 $\mathrm{VGCF}$ 의 부극용 도전재로서의 특 성을 평가하였다.

\section{3. 결과 및 고찰}

\section{$3.1 \mathrm{VGCF}$ 의 입도와 부극의 $\mathrm{SEM}$ 분석}

본 연구에서 사용된 $\mathrm{MCMB}$ 는 Osaka gas사에서 제조한 $\mathrm{MCMB} 2528$ 로서 Fig. 1의 전자현미경 사진과 Fig. 2의 입 도분석 결과에 나타낸 바와 같이 약 $25 \mu \mathrm{m}$ 의 평균 직경을 갖 고 있는 구형의 부극 활물질이다. 도전재로서의 특성 평가에 사

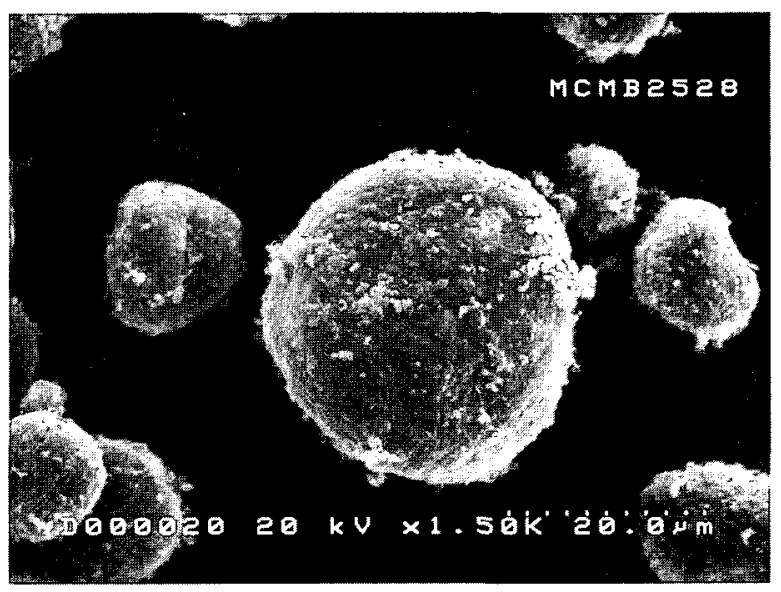

Fig. 1. SEM image of MCMB 2528.

Table 1. Testing conditions adopted to evaluate the performance of LPB.

\begin{tabular}{|c|c|c|c|c|}
\hline & Condition & Formation & Rate Capability & Cycle Capability \\
\hline \multirow{3}{*}{ Charge } & Rest Time & $30 \mathrm{~min}$ & $30 \mathrm{~min}$ & $30 \mathrm{~min}$ \\
\hline & Constant Current & $0.05 \mathrm{C}$ & $0.1 \mathrm{C}$ & $0.05 \mathrm{C}$ \\
\hline & Constant Voltage & $4.2 \mathrm{~V}$ & $4.2 \mathrm{~V}$ & $4.2 \mathrm{~V}$ \\
\hline \multirow{3}{*}{ Discharge } & Rest Time & $30 \mathrm{~min}$ & $30 \mathrm{~min}$ & $30 \mathrm{~min}$ \\
\hline & Constant Current & $0.05 \mathrm{C}$ & $2 \mathrm{C}$ & $0.05 \mathrm{C}$ \\
\hline & Cut Off & $2.7 \mathrm{~V}$ & $2.7 \mathrm{~V}$ & $2.7 \mathrm{~V}$ \\
\hline \multirow{3}{*}{ Discharge } & Rest Time & & $30 \mathrm{~min}$. & \\
\hline & Constant Current & & $1 \mathrm{C}$ & \\
\hline & Cut Off & & $2.7 \mathrm{~V}$ & \\
\hline \multirow{3}{*}{ Discharge } & Rest Time & & $30 \mathrm{~min}$. & \\
\hline & Constant Current & & $0.5 \mathrm{C}$ & \\
\hline & Cut Off & & $2.7 \mathrm{~V}$ & \\
\hline \multirow{3}{*}{ Discharge } & Rest Time & & $30 \mathrm{~min}$. & \\
\hline & Constant Current & & $0.25 \mathrm{C}$ & \\
\hline & Cut Off & & $2.7 \mathrm{~V}$ & \\
\hline \multirow{3}{*}{ Discharge } & Rest Time & & $30 \mathrm{~min}$. & \\
\hline & Constant Current & & $0.1 \mathrm{C}$ & \\
\hline & Cut Off & & $2.7 \mathrm{~V}$ & \\
\hline
\end{tabular}




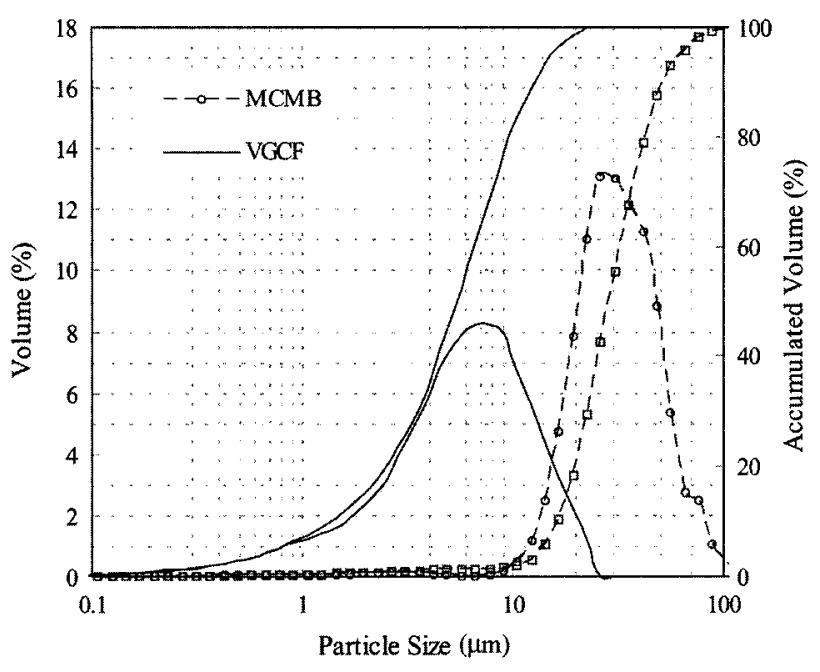

Fig. 2. Particle size distribution of VGCF and MCMB 2528.

용된 VGCF는 Showa Denko K.K.에서 제조한 것이었다. 상기 회사의 $\mathrm{VGCF}$ 중에서 전도도가 상대적으로 높은 흑연화 $\mathrm{VGCF}$ 를 실험에 사용하였다. $\mathrm{VGCF}$ 는 직경이 $150 \sim 200 \mathrm{~nm}$ 이고 길 이가 10 20 $\mu \mathrm{m}$ 인 섬유 형상으로 보고 되어 있다. 전자현미경 으로 관측한 Fig. 3 의 결과에서는 수지상 입자들의 응집체로 존재하였다. $\mathrm{VGCF}$ 의 입도를 측정하기 위해 초음파로 5 분간 분산시킨 후 으로 측정한 입도 분석 결과는 Fig. 2에 나타낸 바와 같이 약 $7 \mu \mathrm{m}$ 평균 입도를 나타내었다. 비표면적은 $13 \mathrm{~m}^{2} / \mathrm{g}$ 으로 타 도전재의 경우와 비교 시 상대적으로 적어 수 분 흡착량이 매우 적은 특성을 보인다. 또한 진밀도 $2.0 \mathrm{~g} / \mathrm{cm}^{3}$, 겉보기 밀도 $0.04 \mathrm{~g} / \mathrm{cm}^{3}$ 으로 밀도가 낮으며, 분체 전도도는 1.2 $\times 10^{-2} \mathrm{~S} / \mathrm{cm}$, 단섬유 전도도는 $1 \times 10^{-4} \mathrm{~S} / \mathrm{cm}$ 로 보고 되어 있다.

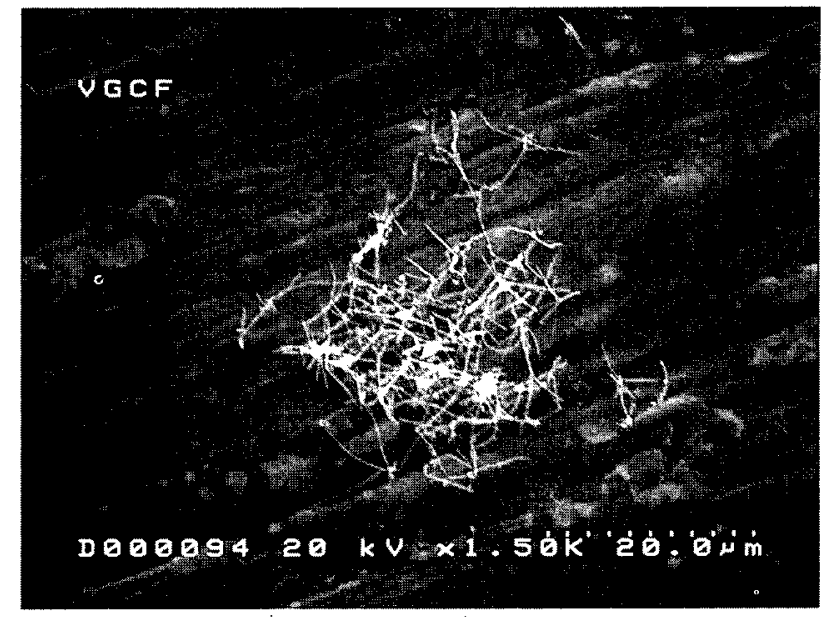

Fig. 3. SEM image of VGCF.

VGCF를 $0,2,4,6$ 및 $8 \mathrm{wt} \%$ 의 함량으로 제조한 부극을 건 조한 후 표면을 전자현미경 사진으로 분석한 바, 각각 Fig. 4 의 (a), (b), (c), (d) 및 (e)와 같이 나타났다. VGCF를 포함한 경우 $\mathrm{MCMB}$ 표면이 $\mathrm{VGCF}$ 로 덮여 있었으며, $\mathrm{MCMB}$ 입자 사이에 $\mathrm{PVDF}$ 와 혼재하고 있음을 확인하였다. 각 함량별로 보 면, $\mathrm{VGCF}$ 가 첨가되지 않은 부극은 $\mathrm{PVDF}$ 가 $\mathrm{MCMB}$ 사이에 덩어리로 존재하며, $\mathrm{VGCF}$ 가 $2 \mathrm{wt} \%$ 첨가된 부극에서부터 $\mathrm{VGCF}$ 와 $\mathrm{PVDF}$ 가 혼합되어 $\mathrm{MCMB}$ 입자 사이에 존재하는 것 을 확인할 수 있었다. VGCF가 $4 \mathrm{wt} \%$ 첨가된 부극은 $2 \mathrm{wt} \%$ 첨가된 부극의 경우와 유사한 형태로 존재하였으며, $\mathrm{VGCF}$ 가 $6 \mathrm{wt} \%$ 이상 첨가된 부극은 $\mathrm{PVDF}$ 와 $\mathrm{VGCF}$ 혼합체가 $\mathrm{MCMB}$ 입자 사이 뿐만 아니라 표면 전체를 덮고 있는 것을 확인하였 다.

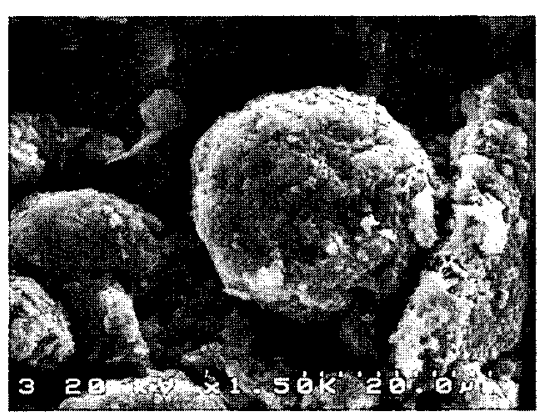

(a) $\mathrm{MCMB} / \mathrm{VGCF} / \mathrm{PVDF}=91 / 0 / 9 \mathrm{wt} \%$

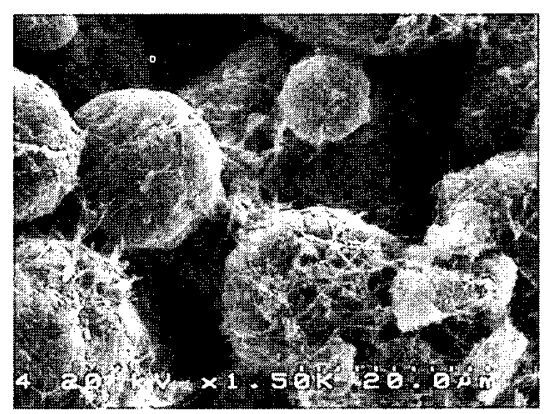

(b) $\mathrm{MCMB} / \mathrm{VGCF} / \mathrm{PVDF}=89 / 2 / 9 \mathrm{wt} \%$

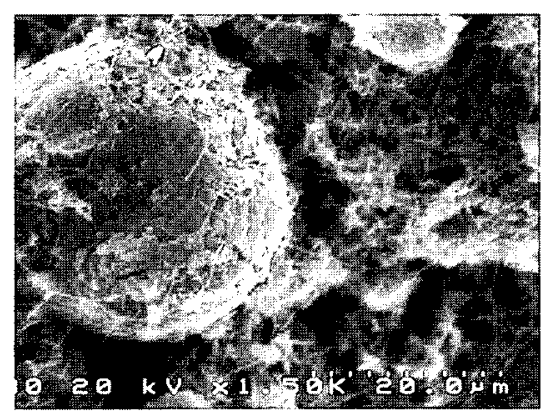

(c) $\mathrm{MCMB} / \mathrm{VGCF} / \mathrm{PVDF}=87 / 4 / 9 \mathrm{wt} \%$

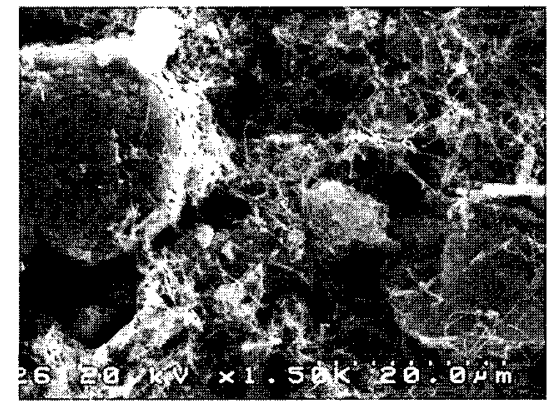

(d) $\mathrm{MCMB} / \mathrm{VGCF} / \mathrm{PVDF}=85 / 6 / 9 \mathrm{wt} \%$

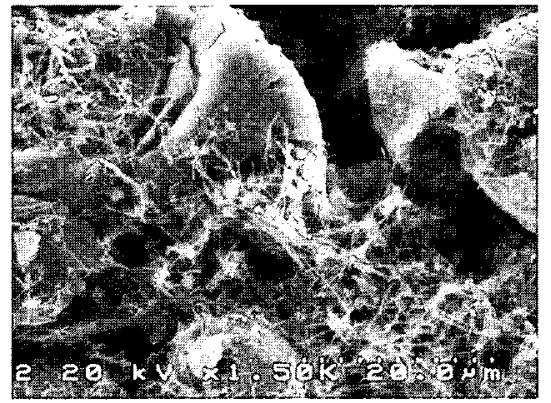

(e) $\mathrm{MCMB} / \mathrm{VGCF} / \mathrm{PVDF}=83 / 8 / 9 w \mathrm{w} \%$

Fig. 4. SEM images of MCMB electrodes with different VGCF contents. 


\section{2 부극 도전재로서 VGCF의 특성}

각각의 전극을 건조 후 초기 두께 대비 $75,70,65,60 \%$ 로 압착한 후에 측정한 저항으로부터 전도도를 구한 결과, Fig. 5 와 같이 실험에 사용한 부극 조성에서 압착율에 따라 전도도가 증가하다가 압착율이 $70 \%$ 일 때 가장 큰 전도도를 나타내었다. $70 \%$ 이상 압착한 경우 압착율 증가에 따라 전도도가 감소하였 다. 실험 범위의 조성에서는 VGCF가 $6 \mathrm{wt} \%$ 첨가된 부극의 전 도도가 가장 높았으며 압착두께가 초기두께의 $70 \%$ 에서 $1.73 \times$ $10^{-3} \mathrm{~S} / \mathrm{cm}$ 의 전도도를 나타내었다.

$0.05 \mathrm{C}$ 의 저전류로 각각의 전지들을 formation 시킨 후에 $\mathrm{AC}$ impedance analyzer로 내부저항을 측정한 결과, VGCF 도전재 $6 \mathrm{wt} \%$ 를 첨가한 부극으로 제조한 전지의 내부저항은 $0.918 \Omega$ 으로 가장 적은 값을 나타내었으며, $\mathrm{VGCF}$ 가 첨가되지 않은 부 극으로 제조한 전지의 내부저항이 $1.59 \Omega$ 으로 가장 높았다. Fig. 6 에서와 같이 전지의 내부저항은 부극의 VGCF 첨가량에

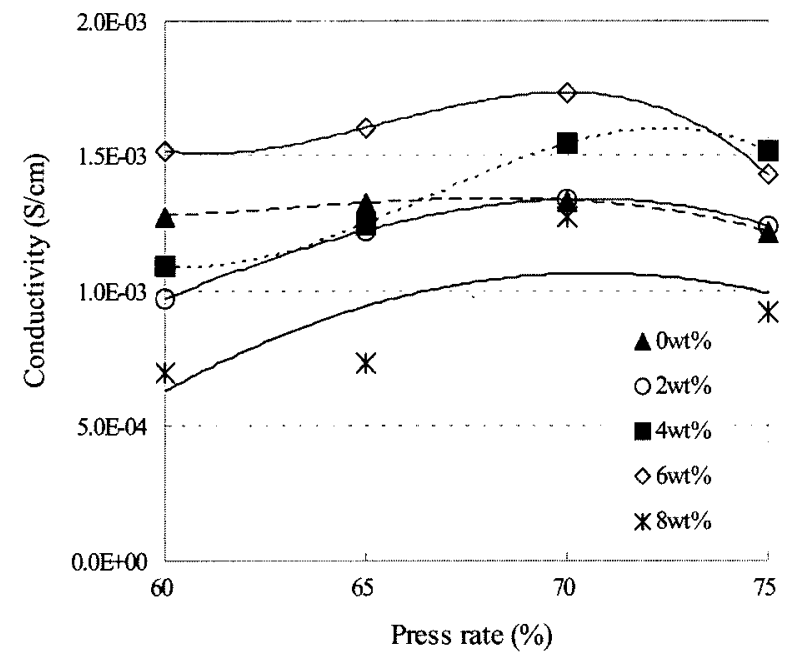

Fig. 5. Specific conductivity of MCMB based anode with different VGCF contents.

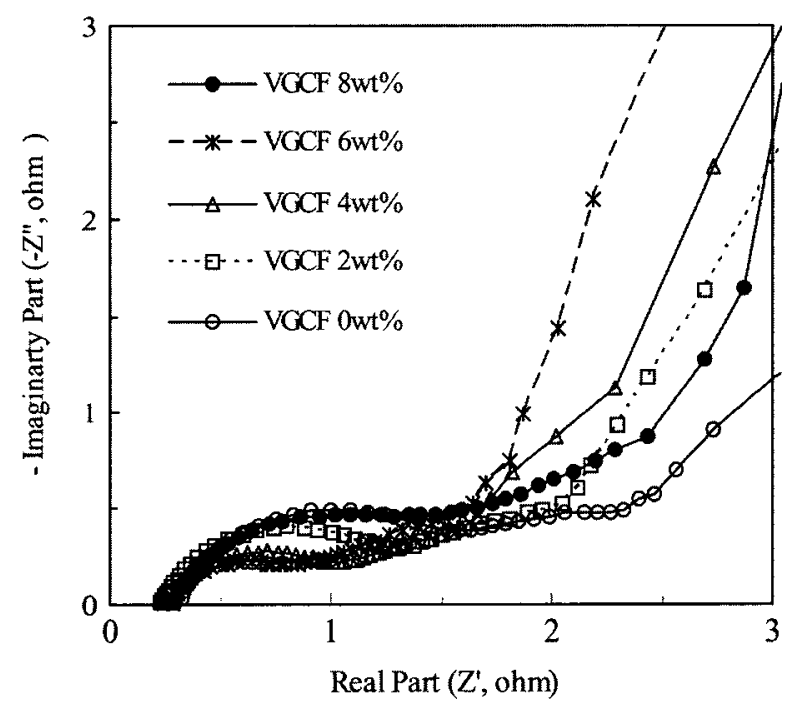

Fig. 6. AC impedance spectra of LPB with MCMB anode containing different amounts of VGCF.
반비례하여 $6 \mathrm{wt} \%$ 가 첨가될 때까지는 감소하였으나 $6 \mathrm{wt} \%$ 이 상으로 첨가량을 늘렸을 경우에는 반대로 내부저항은 증가하였 다. 따라서 $6 \mathrm{wt} \%$ 이상의 $\mathrm{VGCF}$ 를 첨가하는 것은 내부저항 감소 측면에서는 바람직하지 않음을 알 수 있다. 이는 $\mathrm{VGCF}$ 의 수지상 입자들의 응집체인 외형으로 인해 $\mathrm{VGCF}$ 가 $6 \mathrm{wt} \%$ 가 첨가될 때까지는 활물질 입자 사이의 도전경로가 원활히 구성 되도록 만들어 주지만 $6 \mathrm{wt} \%$ 이상의 첨가량에서는 겉보기 밀 도가 $0.04 \mathrm{~g} / \mathrm{cm}^{3}$ 으로 낮아 부피가 큰 VGCF가 활물질 입자 사이에 전자전도도 향상에 필요량 이상으로 존재하게 되어 활 물질 사이를 이격시켜 전도도가 감소하는 것으로 해석할 수 있 다. 또한 bulky한 VGCF 첨가 전극을 압착할 경우, 섬유 형태 이므로 최밀충진이 이루어지지 못하고 전극 내부에 미세 공간 의 잔존으로 인해 VGCF들끼리 반발을 하게 되어 활물질 사이 를 이격시킴으로써 전도도가 감소한 결과이다.

Formation 에서의 Ah efficiency는 $\mathrm{VGCF}$ 의 첨가량 증가에 따라 점진적으로 감소하였다. Fig. 7 에서와 같이 VGCF가 첨 가하지 않은 전지는 $74 \%$ 였으나, $\mathrm{VGCF}$ 가 $8 \mathrm{wt} \%$ 첨가한 전지 는 $64 \%$ 로 크게 감소하였다. 이는 $\mathrm{VGCF}$ 또한 부극활물질로 사용될 수 있는 흑연계 물질이므로 전극표면의 기능기와 유기 전해액의 비가역적 전기화학 반응에 기인한 결과이다. ${ }^{6)}$ 부극에 서의 1 차 비가역 비용랑은 활물질의 비표면적에 비례하므로 비 표면적이 $\mathrm{MCMB}$ 보다 큰 $\mathrm{VGCF}$ 가 첨가되어서 제 일차 $\mathrm{Ah}$ 효율이 감소되었다. 고전류 방전에서 점차적으로 저전류 방전으 로 행한 signature method ${ }^{7)}$ 를 적용한 rate capability 실험에서 VGCF 첨가량에 비례하여 고율의 방전용량이 증가되었다. Fig. 8 에서와 같이 $\mathrm{VGCF}$ 를 첨가하지 않은 전지는 $\mathrm{VGCF} 4 \mathrm{wt} \%$ 첨가한 전지의 $2 \mathrm{C}$ rate에서 방전용량의 $50 \%$ 이었으나 $\mathrm{VGCF}$ 가 $2 \mathrm{wt} \%$ 첨가된 전지는 $84 \%$ 였다. $\mathrm{VGCF}$ 가 $4 \mathrm{wt} \%$ 첨가된 전지의 $2 \mathrm{C}$ rate에서 방전용량은 $93 \%$ 로 $\mathrm{VGCF}$ 를 첨가하지 않 은 전지에 비해 $43 \%$ point 가 향상되었다. $4 \mathrm{wt} \%$ 이상의 $\mathrm{VGCF}$ 를 첨가하여도 $2 \mathrm{C}$ rate에서 $\mathrm{LPB}$ 의 방전 용랑이 $93 \%$ 로 더 이상 개선되지 않았다.

Fig. 9에 VGCF 첨가량에 따른 전지의 수명 특성을 나타내 었다. 상온의 충방전 cycling 실험 결과로부터 도전재를 첨가하

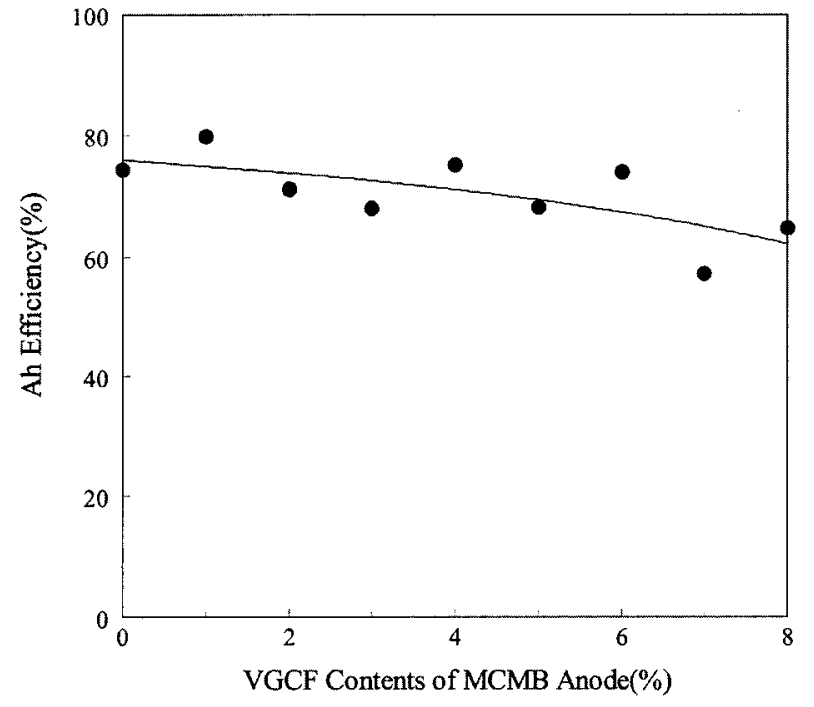

Fig. 7. The initial Ah efficiency of LPB cells with anodes of different VGCF content. 


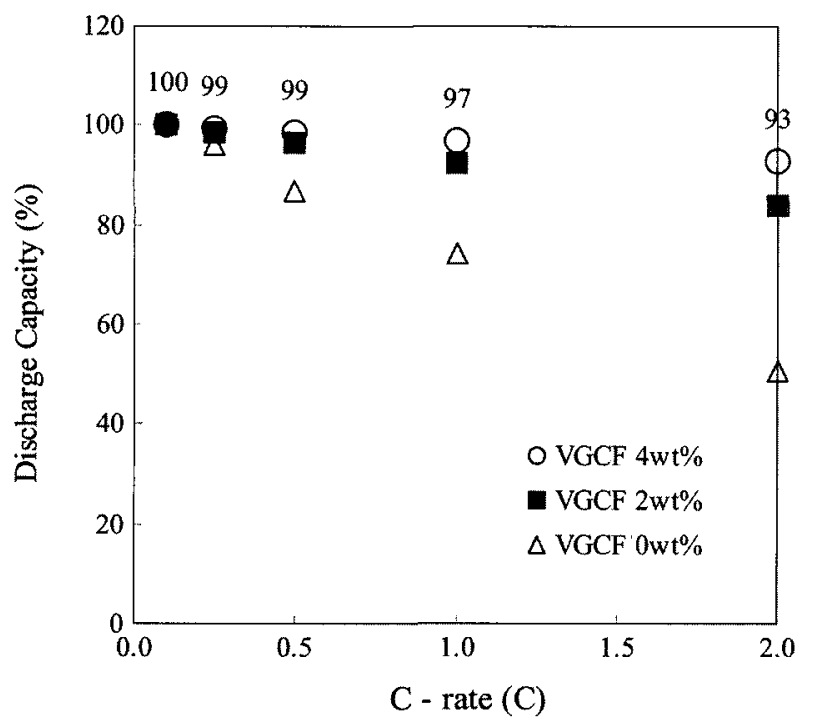

Fig. 8. Rate capability of LPB using anodes with different VGCF contents.

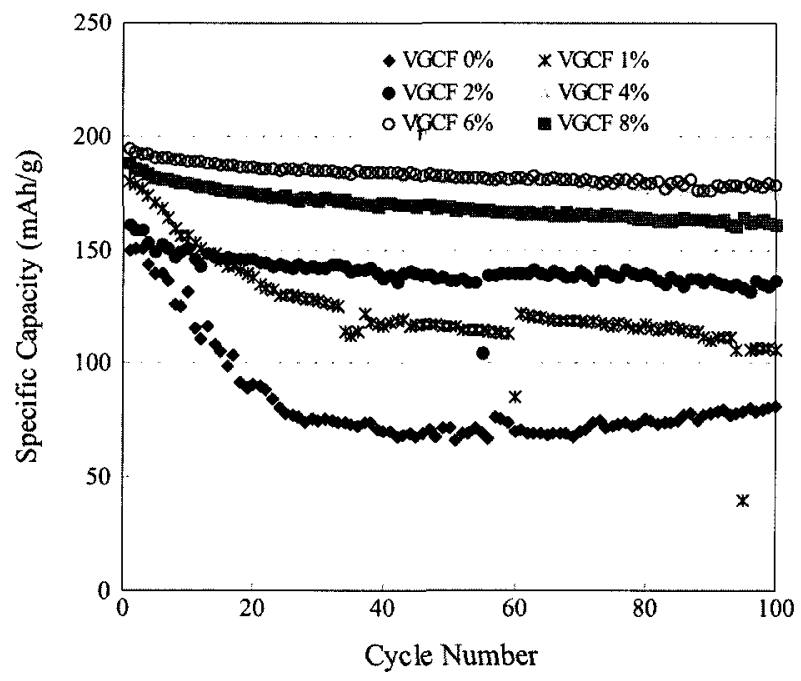

Fig. 9. Cycling properties of LPB using MCMB anodes with different VGCF contents.

지 않은 부극을 채용한 전지는 초기 $30 \mathrm{cycle}$ 까지 급격한 비 용량의 감소를 나타내었다. $\mathrm{VGCF}$ 의 첨가량이 $2 \mathrm{wt} \%$ 인 부극을 채용한 전지는 $\mathrm{VGCF}$ 를 첨가하지 않은 전지에 비해 다소 개선 된 cycling 특성을 나타내었으며, 급격한 비용량의 변화 없이 $165 \mathrm{mAh} / \mathrm{g}(\mathrm{MCMB}$ 기준)에서 충방전 횟수에 비례하여 서서히 감소하였다. $\mathrm{VGCF}$ 를 $4 \mathrm{wt} \%$ 첨가한 부극을 채용한 전지는 $6 \mathrm{wt} \%$ 첨가한 부극을 채용한 전지와 비숫한 cycling 특성을 보 였다. $2 \mathrm{wt} \%$ 의 $\mathrm{VGCF}$ 를 첨가한 부극을 채용한 전지에 비해 4 와 $6 \mathrm{wt} \%$ 를 첨가한 부극을 채용한 전지는 약 $45 \mathrm{mAh} / \mathrm{g}$ 의 비 용량이 증가되었으며, 가장 안정된 cycling 특성을 보였다. $\mathrm{VGCF}$ 의 첨가량 $4 \mathrm{wt} \%$ 까지는 첨가량에 비례하여 수명 특성이 개선되었으나 $6 \mathrm{wt} \%$ 이상 $\mathrm{VGCF}$ 를 첨가한 부극을 채용한 전지 는 $6 \mathrm{wt} \%$ 의 $\mathrm{VGCF}$ 를 첨가한 부극을 채용한 전지에 비해 약 $15 \mathrm{mAh} / \mathrm{g}$ 의 비용량이 감소하였다.

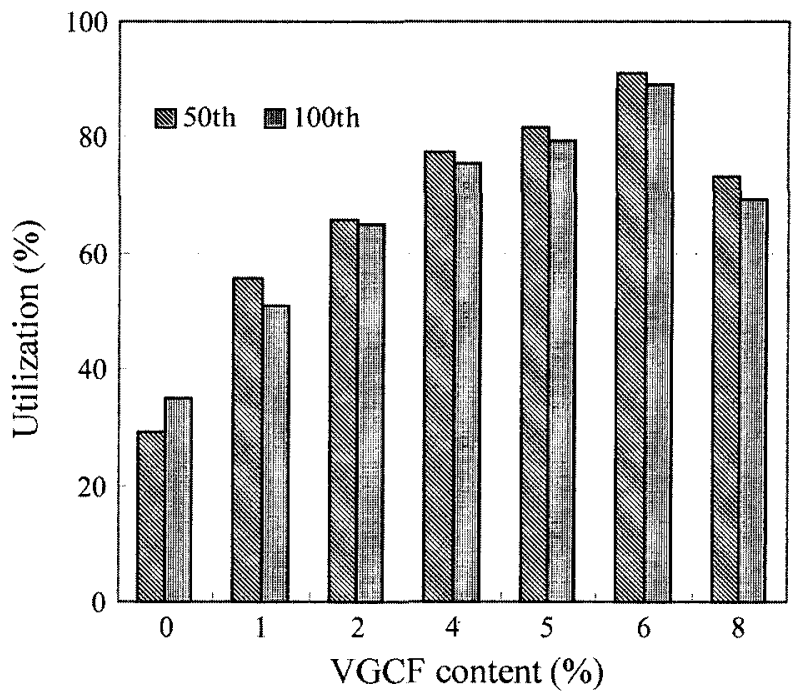

Fig. 10. Comparision of utilization of LPB cells with anodes of different VGCF contents anodes after 50 \& 100 cycles.

Fig. 10 은 도전재의 첨가량에 따른 각 전지의 이용률을 나타 낸 것으로서 초기 방전 용량 대비 방전 용량의 비인 전지 이용 율 역시 수명 특성 실험의 결과와 유사한 경향의 결과를 나타 내었다. 도전재 첨가량이 $6 \mathrm{wt} \%$ 인 경우 $100 \mathrm{cycle}$ 에서의 이용 률이 $90 \%$ 로 나타났으며, 타 비율의 첨가량 경우에 $90 \%$ 이하 로서 $6 \mathrm{wt} \%$ 의 경우 가장 높은 이용율을 나타내었다.

\section{4. 결 론}

VGCF를 부극용 도전재로 채택하여 이의 첨가량에 따른 전지 의 내부저항 및 전지 특성을 연구하였다. $\mathrm{MCMB}$ 활물질에 대 하여 PVDF 결합제릅 $9 \mathrm{wt} \%$ 사용하는 조성에서 $\mathrm{VGCF}$ 를 도 전재로 첨가할 시에는 $6 \mathrm{wt} \%$ 의 비율에서 최적의 전지 성능을 나타내었다. 초기두께 대비 압착두께를 $70 \%$ 로 압착하였을 때 의 전도도가 $1.73 \times 10^{-3} \mathrm{~S} / \mathrm{cm}$ 이고, 전지의 내부저항은 $793 \mathrm{~m} \Omega$ 이었으며, 제 일차 $\mathrm{Ah}$ 효율은 $74 \%$ 였다. $\mathrm{VGCF}$ 를 $6 \mathrm{wt} \%$ 첨가 한 부극으로 제조한 전지는 $\mathrm{C} / 10$ 의 방전용량 대비 $2 \mathrm{C}$ 의 방전 용랑은 $93 \%$ 로 우수하였으며, cycling 특성과 수명 특성을 현저 히 개선하였을 뿐만 아니라 100 cycle에서의 이용률은 $90 \%$ 로 서 가장 높은 이용율을 나타낼 수 있었다.

\section{참고문헌}

1. C. Berthier, W. Gorecki, M. Minier, M. B. Armand, J. M. Chabagno, and P. Rigaud, Solid State Ionics, 11, 91 (1983).

2. M. A. Ratner and D. F. Shriver, Chem. Rev., 88, 109 (1988).

3. D. G. H. Ballard, P. Cheshire, T. S. Mann, and J. E. Przeworski, Macromolecules, 23, 1256 (1990).

4. "1999년 전지기술 심포지엄 자료집”, 한국공업화학회외 3개 기관, 韓國 (1999).

5. 문성인 와, “고체고분자전해질리틈전지(LPB)개발” 보고서, 산업자 원부, 墘國 (1998).

6. 金相即 역, “Lithium Ion二次電地”, 日干汇業新闻社土, Japan (1996).

7. A. Madronero, A. Hendry, and L. Froyen, Composites Science and Technology, 59, 1613 (1999). 